\title{
A Short Political Biography of Kibur Ato Haddis Alemayehu
}

\author{
Alemu Alene Kebede \\ Debre Markos University, Ethiopia. \\ Received 13 June, 2014; Accepted 21 October, 2014
}

\begin{abstract}
The main purpose of this paper is to reconstruct the political biography of Kibur Ato ${ }^{\mathrm{ii}}$ Haddis Alemayehu who was one of the senior officials of Ethiopia during the reign of Emperor Haile Selassie I and the author of the most accomplished Amharic novel, Feqer Eska Meqaber ("Love unto Grave"). In order to undertake this study, both primary and secondary sources were used. The source analysis revealed that after the liberation of Ethiopia from Italian occupation in 1941, Haddis served his country at different senior governmental posts, among others, as Director, Director General and Vice Minister in the Ministry of Foreign Affairs, Minister of State in the Ministry of Education, and Minister of the Ministry of Planning and Development. He was Ethiopian Consul to Jerusalem, First Secretary of Ethiopian Legation in Washington D.C., Ethiopian Ambassador and Permanent Representative to the UN and Ambassador to Great Britain and the Netherlands. Besides, he also participated in a number of international as well as continental conferences. In his dealing with other countries on behalf of the Ethiopian government, Haddis was committed to protect Ethiopia's interest and sovereignty. At home, Haddis had a character of truthful and meticulous administrator and bold enough to comment any mistake of the government. Thus, the consideration of Haddis Alemayehu's political biography helps not only to know him at some depth but also to comprehend the nature of the past feudo-capitalist system of Ethiopia.
\end{abstract}

Key words: Haddis, Minister, Ambassador, Diplomat, Foreign Affairs.

\section{INTRODUCTION}

In the past century, distinguished personalities had emerged in the province of Gojjam, North-western Ethiopia. These personalities served their country, among others, as provincial governors, resistance leaders, politicians and literary men. One of these personalities who played significant role in the politics and literary development of Ethiopia was Kibur A to Haddis Alemayehu (Figure 1).
Haddis Alemayehu was one of the senior officials of Ethiopia during the reign of Emperor Haile Selassie I. After liberation from Italian occupation in 1941, Haddis served his country at different governmental positions and represented the government of Ethiopia at global and continental levels. He also published seven fictional and non-fictional books in Amharic. As a result, Haddis

E-mail: a lemualene@gmail.com. Tel: +251 0912051712.

Author agree that this article remain permanently open access under the terms of the Creative Commons Attribution Lic ense 4.0 Intemational Lic ense 
attracted the attention of some researchers. However, the studies previously undertaken on the life and career of Haddis Alemayehu (Molvaer, 1974; Fentahun, 2000 Ethiopian Calendar, - hereafter - and Girma, 2004) had several problems. Firstly, these studies did not make careful examination, checking and cross-checking of primary and secondary sources. Due attention was not given to collect information from individuals who knew Haddis closely and who worked with him in different governmental positions. Sources available in Haddis's home and in Institute of Ethiopian Studies were not consulted. Secondly, the previous studies confined themselves in listing the positions held by Haddis in Haile Selassie's government than considering the various activities performed by him in those positions. Therefore, one of the means to fill this gap is undertaking a research by carefully examining primary and secondary sources for the reconstruction of the political biography of Kibur Ato Haddis Alemayehu. Thus, this study was initiated to fill the gap already mentioned. The general objective of this study was to examine the political career of Kibur Ato Haddis Alemayehu as one of the senior officials of Haile Selassie's government and to draw lessons from his contributions. The specific objectives were identifying the senior governmental positions that Haddis had active involvement, examining Haddis's contribution for his country while working at different governmental positions and evaluating the nature of relationship that existed between Haddis and Haile Selassie's government.

\section{MATERIALS AND METHODS}

This research was undertaken by employing a historical research design based on qualitative method. Both primary and secondary sources were used in this study. The primary sources are Haddis's own manuscripts obtained in his home and books written by him. The secondary sources consist of both published and unpublished materials written in relation to Haddis. Oral information obtained through interview conducted with individuals who closely knew and worked with Haddis was also used in this study. Some of the sources were collected in 1998 while the researcher was undertaking an investigation on related issues for academic purpose. Additional secondary sources [Fentahun (2000), FikreSelassie (2006), Girma (2004)] were reviewed in 2013 and 2014 and used in this study.

\section{Early life of Kibur Ato Haddis Alemayehu}

Haddis was born in 1909 from Aleqa ${ }^{1}$ Solomon Hailu and Weyzaro ${ }^{2}$ Desta Alemu in Indodam Kidane Mihret, a

\footnotetext{
${ }^{1} \mathrm{~A}$ title given for a learned priest and the head of a church
}

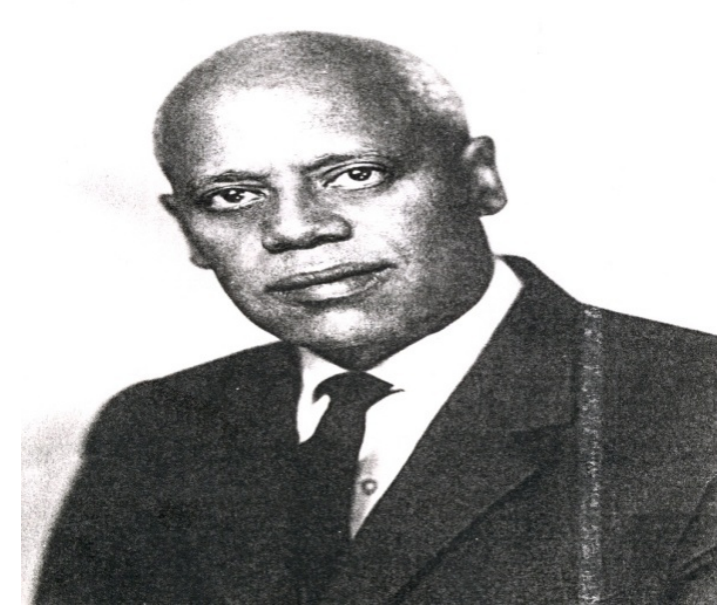

Figure 1. Photograph of Haddis.

village in Gozamin Wereda (district), Debra Marqos Awraja ( sub-province), in the province of Gojjam. ${ }^{3}$ His maternal grandfather, Alemu Seyoum, was a Zema (church melody) teacher in the monastery of Indodam Kidane Mihrat. It was there that Haddis started to learn Geez letters at the age of six. ${ }^{4}$

During his formative years, Haddis attended different levels of ecclesiastical education in the monasteries of Indodam Kidane Miheret, Debra Elyas, Debra Werq and Dimma Giorgis in Gojjam. He attended Deguwa, one of the contents of Zemabet (school of church melody), in Indodam Kidane Mihret and Debra Elyas, Qene (Geez poetry) in Debra Elyas, Debra Werq and Dimma Giorgis, Metshafbet (interpretation of the holy books) in Dimma Giorgis. ${ }^{5}$ In his study of ecclesiastical education, Haddis was a shining student who excelled his friends. It was while attending Metshafbet that Haddis and his friends such as Samuel Tedla, Tamiru Melaku, Betratsadiq Kassa, Mekonnen Chekol and Yiheyis entered Addis Ababa, accompanying their teacher, Mergeta ${ }^{6}$ Belay, who decided to go to Shoa, his birth place, because of his disagreement with the priests of Dimma Giorgis (Figure $1)^{7}$

\footnotetext{
${ }^{2}$ A title given for married woman

${ }^{3}$ Reidulf,K. Molvaer, Black Lions: The Creative Lives of Modern Ethiopia's literature Giants and Pioneers (Lawrenceville: NJ Red Sea Press, 1966), p. 134

${ }^{4}$ Ibid., pp.134-35;Oral Informant (hereafter O. I.) Blatta Mehari Kassa (age 93, interviewed in Addis Abeba on 20 Dec. 1998). Blatta was a title given in the twentieth century to government officials of the director-general level or equivalent

${ }^{5}$ Feekare (Private Bulletin), Vol-I, No. 1, Yekatit 1985 E.C, p.4; O.I. Kibur Ato Haddis Alemayehu (age 88, interviewed in Addis Abeba on 13 Jan. 1998)

${ }^{6}$ A title given for those who attended higher level of church education and for choir or chant leaders in Ethiopian Orthodox Church

${ }^{7}$ Bekur (Bulletin of Amhara National Regional State), Sene 1989 E.C., No.6, p.26
} 
Once they reached Addis Ababa, Haddis and his friends took lodging near patriarch's compound, where destitute men used to reside themselves. As they spent more time in Addis Ababa, Haddis and his friends began to visit different places. This gave them the chance to meet with Ato Ayalew Negussie, a Gojjame who was teaching in Swedish Mission School. After his contact with Haddis and his friends, Ato Ayalew advised them to enter into Swedish Mission School and attend modern education. However, Haddis had a fear that mission school would convert him to Catholicism. As a result, he was reluctant to accept his advice. However, Haddis had no relative and supporter in Addis Ababa and had to beg in order to get a living. He was also in a state of confusion for he was new to urban life. His friends also told him to accept the advice of Ato Ayalew. All these contributed to the change of his mind and finally decided to join the school. ${ }^{8}$

Then, Haddis and his friends went to Swedish Mission School with priest Badema, a Gojjame who had close relation with the head of Swedish Mission School. After long conversation, the head of the mission school, Mr. Sharne, promised their enrolment after tentative stay for three weeks. Finally Haddis and his friends were accepted as regular boarding students in Swedish Mission School in 1925 and attended grade one and two in this school. ${ }^{9}$

Gradually, Haddis and his friends understood the advantage of modern education and sought to join government school. The intention of Haddis and his friends was realized when they easily won the help of Ras Hailu Tekla-Haymanot, the hereditary governor of Gojjam (1901-1932), who was financing Gojjame students in Teferi Mekonnen School. Therefore, Haddis and his friends were paid ten birr (Ethiopian currency) per month from Ras Hailu's treasury. Haddis attended Teferi Mekonnen Elementary School from grade three to grade six. ${ }^{10}$

Meanwhile, a strike caused by problems in the teaching-learning process broke out in Teferi Mekonnen Elementary School. Adult students were suspected of instigating the strike and some of those above eighteen years were ordered to learn living outside the school compound. This means they were denied boarding facilities in the school. As a result, only those students who had relatives in Addis Ababa were able to continue their education. But those who came from provinces and who did not have relatives and supporters in the capital could not afford and were forced to stop their education. Haddis was one of the latter students. ${ }^{11}$

\footnotetext{
${ }^{8}$ Ibid., pp. 22-7; O.I. Blatta Mehari Kassa

${ }^{9}$ Ibid.

${ }^{10}$ O.I. Kibur Ato Haddis Alemayehu

${ }^{11}$ O.I. Ato Amanuel Abreha (age 84, interviewed in Addis Abeba on 16 December
}

After he was denied of boarding facilities in Teferi Mekonnen Elementary School, Haddis had taken a teacher training course given in Menelik II School and became a teacher in Swedish Mission School, where he was for the first time been introduced to modern education. However, Haddis taught only for about nine months in this school. Because in 1931, he was ordered to go to the province of Gojjam, to serve the customs office of Dangila town. In fact, Haddis was sent to Dangila to inspect the activity of the British consulate found in the town. ${ }^{12}$

Dangila was a well-known slave market in Gojjam province in the early twentieth century ${ }^{13}$ and the British set up consulate office in the town and the consulate used to report to its government regarding the brisk slave trade conducted in the town. When Haddis reached Dangila, the interpreter of the consulate office, Zewde Kidane-Weld, through whom Haddis could contact the consul, was sick. As a result, Zewde was replaced by Qegnazmach ${ }^{14}$ Hiwet Hedaru. As soon as Haddis began to inspect the activity of the British consul through Hiwet, Major Chessman, the British consul in Dangila, set out his journey from Bahir Dar to the Sudan to visit the Blue Nile.

After completing his visit to the Blue Nile, Major Chessman returned to his consulate office in Dangila town. However, the consul did not stay longer in Dangila. Soon, he closed his office and went to England for his own purpose. As a result, Haddis was forced to change his task and began to work as inspector in the customs office of Dangila. But Haddis also stayed in this post for a short period of time because he was ordered by the government to involve in the operation of emancipating slaves in Dangila. ${ }^{15}$ This duty was given to him as a result of domestic and foreign pressures on the Ethiopian government to abolish slavery and slave trade. ${ }^{16}$

Although series of proclamations were issued by the Ethiopian government by 1923 and after, the practice of slave trade and slavery continued secretly in the region. Because of this, in 1934 Haile Sellase set up 26 local offices to control slave trade. ${ }^{17}$ At this time, Blatta HeleteWerq, the head of Agew Meder and Achefer customs office, was nominated as emancipist of slaves in his region. It was at this time that Helete-Werq asked Haddis

1998); Haddis Alemayehu, Tezetta, ("Memory”). (Addis Abeba: Kuraz Publishing Agency, 1885 E. C.), p.141

${ }^{12}$ Molvaer, pp. 135-37; O.I. Kibur Ato Haddis Alemayehu

13 Abdulsamed Haji Ahmed, "Bure-A study of Long Distance Trade 1900 1935," B.A. Thesis (Addis Abeba University, 1977), p. 25

${ }^{14}$ A Politico-military title which was given for the 'commander of the gate'

15 Haddis, Tezetta, p.19

${ }^{16}$ O.I. Blatta Mehari Kassa

${ }^{17}$ Bahru, Zewde. (2005). A History of Modern Ethiopia: 1855-1991. Second Edition. Addis Ababa: Addis Abeba University Press, p. 94; Richard, A. Greenfield, Ethiopia: A New Political History (New York: Frederick A. Preager, 1965), p.173 
to voluntarily participate in the operation of emancipating slaves. Haddis also welcomed the request and joined the workers assigned to this purpose, and began to hunt the slave traders. Within a short period of time, they emancipated many slaves and placed them around Dangila town. ${ }^{18}$

After accomplishing his part in the emancipation of slaves, Haddis was assigned to organize a school in the building of the British consulate of Dangila town. When the school was opened, Haddis became both the director and teacher of the school that became the first of its kind both in Dangila town and in the whole of AgewMeder. The nobles of SebatBet Agew (the Seven House of Agew) used to send their sons to this school for education. ${ }^{19}$

At the end of March 1935, Haddis was transferred to Debra Marqos and began to teach in Tekla Haimanot Elementary School, which was established in 1934. He taught English and Arithmetic in grade three and four. He also taught the children of the then governor of Gojjam, Ras Emeru Haile Selassie, namely Marta, Hirut, Yudit and Mikael, and stayed there until the Italian invasion of the country in $1935 / 36 .^{20}$

During the Italian invasion, Haddis joined the forces of Ras Emeru Haile Selassie, the leader of the Ethiopian forces at the Shire front and served as agitator or activist and combatant in the military engagement that took place in the northern front. He also served as purchaser of war provisions in the Sudan after his return from the front. In the early years of Italian occupation he was captured by the fascist forces in the military confrontation that took place against the Italians at Gojjeb River in Kaffa in 1937 and sent to the island of Ponzo in the western Mediterranean, then to island of Lipari, near Sardina (South Italy), and became war prisoner in Italy with Ras Emeru and other Ethiopians for seven years. Haddis was released and came to his country at the end of 1943, three years after the liberation of Ethiopia from fascist occupation. ${ }^{21}$

\section{Kibur Ato Haddis Alemayehu's political career from 1944 to 1959}

The Fascist Italian occupation of Ethiopia had came to an end in 1941, due to the relentless effort made by the joint Anglo-Ethiopian liberation campaign and greater sacrifice of the patriots. After liberation, Emperor Haile Selassie I

\footnotetext{
${ }^{18}$ Haddis, Tezetta, p.19; O.I. Kibur Ato Haddis Alemayehu

${ }^{19}$ Ibid.

${ }^{20}$ Molvaer, p.137; O.I. Lej Mikael Emeru (age 73, interviewed in Addis Abeba on 18 Dec. 1998) and Weyzarit Yudit Emeru (age 75, interviewed in Addis Abeba on 29 Jan. 1998). Lej was a honorific title generally reserved for sons of the royal family and of the upper nobility. It means 'child'. Weyzerit is a title given for unmarried woman.

${ }^{21}$ O.I. Blatta Mehari Kassa; Haddis, Tezetta, pp.95-105
}

was restored to the throne and began to consolidate his political power. ${ }^{22}$

In the post-liberation period, Haddis served his country at different positions. Most of his service was in the area of foreign affairs at domestic and international levels. ${ }^{23} \mathrm{As}$ soon as he came back to the country, Haddis was appointed as Deputy General of Press and Information in the Ministry of Communication. During his brief stay, he was reported to have reorganized the office with man power and enabled it to function properly. ${ }^{24}$ Meanwhile, he was transferred to the Ministry of Foreign Affairs as Director of the American Department. His total service in both offices was, however, less than a year. ${ }^{25}$

In February 1945, Haddis was appointed as Ethiopian consul to Jerusalem, where he stayed for two years, during which he married Kibebe-Tsehay Belay. KibebeTsehay was the great granddaughter of Wagshum ${ }^{26}$ Teferi Wessen and she was taken to Jerusalem and grown up there under the custody of Weyzaro Amarch Walelu, who was leading a monastic life in the Holy Land. ${ }^{27}$ During his stay in Jerusalem, in 1947 Haddis was ordered to attend international conference held in Atlanta City, New Jersey, to talk on the reconstruction of postWorld War II global telecommunication system. Haddis stayed there about five months to participate in series of conferences on behalf of the Ethiopian government. ${ }^{28}$

With the completion of the conference, Haddis became First Secretary of the Ethiopian Legation in Washington D.C. under Ras Emeru Haile Selassie, head of the Legation. Apart from his secretarial duty in this Legation, Haddis worked as an Ethiopian representative to the UN assembly held at irregular interval for short periods. In 1949, he was appointed as Ethiopian representative to the Interim Committee of the General Assembly of the UN and stayed in this office for a year. During his stay in the United States of America, Haddis was attending an evening class in International Law in Washington University. Since he was ordered to return to his country, Haddis was forced to discontinue his study after completing most of the courses offered in the department. Haddis did not return to Washington to complete it and he could not get a diploma in International Law. ${ }^{29}$ Back to Ethiopia, in 1950, he was

\footnotetext{
${ }^{22}$ Christopher, Clapham, Haile Selassie's Ethiopia (New York: Prager, 1969), p.19

${ }^{23}$ Ethiopian Herald, April 13, 1966, p.3; Molvaer, p. 139

${ }^{24}$ O.I. Bitweded Zewde Gebre Hiwet (age 86, interviewed in Addis Abeba on 24 Jan.1998)

${ }^{25}$ Molvaer, p. 139

${ }^{26}$ A title which was given for the governor of the province of Wag in north Wallo

${ }^{27}$ O.I. Dejjazmach Dr Zewde Gebre Selassie ( age 70, interviewed in Addis Abeba on 5 Dec. 1998) and Weyzerit Yudit Emeru

${ }^{28}$ Feekare, p. 28

${ }^{29}$ Molvaer, p. 140; Ethiopian Herald, 1966, p. 3; O.I. Bitweded Zewde Gebre Hiwet
} 
restored to the Ministry of Foreign Affairs as Director General of the Department of Press and International Organization. After serving in this office for two years, Haddis became a Vice Minister in the Ministry of Foreign Affairs, when this position was left vacant due to the transfer of BitwededZewde Gebra-Hiwet, who was sent to New York as Ethiopian Ambassador and Permanent Representative to the UN. ${ }^{30}$

As a Vice Minister of Foreign Affairs, Haddis was reported to have always challenged America's domination of Ethiopia. Above all, he was not in good terms with John $\mathrm{H}$. Spencer, an American adviser of Ethiopia on foreign affairs. ${ }^{31}$ Of course, following the signing of the Ethio-US treaty in 1953, America's influence on Ethiopia particularly in the areas of military organization, communication and education became stronger. This growing influence of America led to bitterness among the educated elites of Ethiopia on the ground that the country had fallen under American imperialism. ${ }^{32}$ Likewise, Haddis was said to have opposed America's endeavor to run Ethiopia according to her interest and Americans attempt to involve deeply in the works of the Ministry of Foreign Affairs. ${ }^{33}$

There are different views on Haddis's ideological alignment. John $\mathrm{H}$. Spencer regarded Haddis as a communist. In his book entitled "Ethiopia At Bay: A Personal Account of Haile Sellase's Years", Spencer asserted that "Ras Imru, Haddis Alemayehu and Sirak Heruy ... were openly communist sympathizers." ${ }^{34}$ Spencer also considered Haddis as one of the authorities in the Ministry of Foreign Affairs who resented Ethiopia's closer tie with the United States following the signing of the treaty on military aid program, ${ }^{35}$ and he asserted that Haddis was one of the senior officials responsible for the strengthening of Ethio-USSR relations. ${ }^{36}$ On the contrary, based on analysis of his literary works, Tsegaye asserted that Haddis prefers western type of government as opposed to socialist democracy. ${ }^{37}$ But informants strongly argued that "Haddis did not have special alignment both to the western and eastern political systems. Instead, his great concern was maintaining Ethiopia's interest and sovereignty." 38 The view of the informants was matched with what Haddis has written on the type of political system Ethiopia needs. In his book entitled Ytyopia Min Aynet Astedader Yasfelgatal? /"What type of government

\footnotetext{
30 Ethiopian Herald, 1966, p. 3; O.I: Bitweded Zewde Gebre Hiwet

${ }^{31}$ O.I. Bitweded Zewde Gebre Hiwet

${ }^{32}$ Bahru, pp. 185-89

${ }^{33}$ O.I. Bitweded Zewde Gebre Hiwet

${ }^{34}$ John H. Spencer, Ethiopia At Bay: A Personal Account of the Haile Silassie

Years (Algonae: Michigan,1984), p. 219

${ }^{35}$ Ibid., pp. 216-17

${ }^{36}$ Ibid., pp. 313-14

37 Tsegaye Haylu , "Haddis Alemayehu as a Social Critic" M.A. Thesis in literature (Addis Abeba University, 1987), p. 14

${ }^{38}$ O.I. Bitweded Zewde Gebre Hiwet and Blatta Mehari Kassa
}

Ethiopia needs?"/, Haddis suggested neither capitalist nor socialist political system, rather a political system designed by taking ideas from both and suited with Ethiopia's history, society and culture. ${ }^{39}$

Due to his regular duty as a diplomat, Haddis had participated in a number of international as well as continental conferences. He was:

-an Ethiopian representative at the 1948 FAO conference held in Rome

-an alternate delegate to the 4th session of the UN General Assembly held at Lake Success ( a village in New York) in 1949.

-a delegate to the UN General Assembly of 1952.

-a delegate to the $6^{\text {th }}$ session of the. UN General Assembly held in Paris in 1954.

-a delegate to the 1964 conference of African Foreign Ministers held in Lagos. ${ }^{40}$

In 1956, Haddis was appointed as an Ethiopian Ambassador and Permanent Representative to the UN, as the second Ethiopian officer to this post, replacing Bitweded Zewde Gebra-Hiwet. One of the major responsibilities of Haddis in this office was to negotiate with the Italians on the boundary problem between Ethiopia and Italian Somaliland. ${ }^{41}$ With regard to the stand of Haddis to the sovereignty of Ethiopia, Spencer pointed out that Haddis was known in "his refusal ever to surrender an atom [a piece] of Ethiopian sovereignty or territory". ${ }^{42}$ It was from this stand that Haddis was said to have chosen as the acting general of Ethiopian delegates dealing with the boundary problem with Italian Somaliland. ${ }^{43}$

The frontier line between the Italian Somaliland and Ethiopia had for long been a source of contest between the two countries and bestowed Italians with a good pretext to carry out their aggressive policy in $1935 .{ }^{44}$ Four years after the end of the Second World War, Italy was once again given a ten year UN trusteeship over her former colony of Somaliland. Since the middle of 1950s, the Ethiopian government began to make efforts to solve the boundary problem with Italian Somaliland. However, the two parties could not reach an agreement. ${ }^{45}$ As a result, by a resolution of the General Assembly in December 1958, King Olaf of Norway was asked to find a

\footnotetext{
${ }^{39}$ Haddis Alemayehu , Ytyopia Min Ayinet Astedader Yasfelgatal ("What Type of Government Ethiopia Needs?”) (Addis Abeba: Birhanena Salam Printing Press, 1966 E.C.), p.19

${ }^{40}$ Ethiopian Herald, 1966, p. 3

${ }^{41}$ O.I. Weyzerit Yudit Emeru and Dejjazmach Dr Zewde Gebre Selassie

${ }^{42}$ Spencer, p. 300

${ }^{43}$ O.I. Bitweded Zewde Gebre Hiwet

${ }^{44}$ John, Markakis, Ethiopia: Anatomy of Traditional Polity (Addis Abeba: Oxford University Press, 1974), p. 368

${ }^{45}$ O.I. Kibur Ato Haddis Alemayehu
} 
basis on which Ethiopia and Italy could start to settle the border dispute involving the former Italian colony, Somaliland. Accordingly, Trygre Lie, Norwegian diplomat and the First Secretary General of the UN was selected for that purpose by king Olaf of Norway. ${ }^{46}$

On August 3, 1959, Lie met Haddis, John H. Spencer and Italian delegates to the negotiation. At every meeting, Haddis' was asked to start the dialogue. This condition gave the Italians ample time to give response to what he demanded. However, the meeting was short lived because the Italians ignored the content of the 1908 treaty and raised different treaties that Italy signed with Britain and France as term of reference to the negotiation. ${ }^{47}$ But Ethiopian delegates also did not accept the points of negotiation presented by the Italians. It was at this point that Lie prepared his own proposal that acknowledged the agreement of 1908, but sought to consider other international treaties for its interpretation. However, both of the delegates were not satisfied with his proposal and this brought the whole process of negotiation between the two parties to an abrupt end. ${ }^{48}$

\section{Kibur Ato Haddis Alemayehu's Political Career from 1960 to 1974 and After}

Haddis took the post of Ambassadorship to the UN for about four years and five months. At the onset of 1961, he became Minister of State in the Ministry of Foreign Affairs for a brief period of time, ${ }^{49}$ during which he wrote and submitted "Leyu Mastawesha" (special note) to Emperor Haile Selassie I. It was dated Tir 23, 1953 E.C. (I February 1961) and dealt with the abortive coup d' et at of December $1960,{ }^{50}$ during the attempt of which Haddis was in New York and was not involved or forced to involve in it. ${ }^{51}$ However, he was well aware of the problems within the country that instigated the coup makers. Thus, in that "Leyu MastaweSha", a document which later on published, with modification and adjustment, as Ityopia Min Aynet Astedader Yasfelgatal? Haddis pointed out what he considered possible causes for the discontent and unrest in the society and forwarded suggestions to prevent the coming of such disturbance and unrest again in the country. ${ }^{52}$

According to Haddis, the root cause for the unrest that took place in December 1960 was the dissatisfaction of the younger generation which was emanated from the

\footnotetext{
${ }^{46}$ Spencer, p. 297

${ }^{47}$ Ibid., pp. 297-99

48 Mesfin Welda-Mariam,, The Background of the Ethio-Somali Boundary

Dispute (Addis Abeba: Haile Sellase I University, 1964), p. 54

${ }^{51}$ O.I. Kibur Ato Haddis Alemayehu

52 "Leyu Mastawesha" ('Special Note”). Tir 23, 1953 E.C, p. 1

51 Molvaer, p. 142

54 "Leyu Mastawesha", p. 1
}

backward socio-economic and political condition of the country. Therefore, Haddis suggested, in his "Leyu Mastawesha", that the only solution to bring about sustainable peace was to undertake reform on the political system of the country and to raise the socioeconomic and political condition of the country and make it a competent nation with other developed countries. Otherwise, Haddis pointed out that another unrest could explode. ${ }^{53}$

Apart from pointing out what needs to be done in his "Leyu Mastawesha", Haddis also openly requested Emperor Haile Selassie I to improve the political system of his government by saying:

The improvement of Ethiopia's administrative system and developmental program is inevitable, tomorrow, if not today; the day after, if not tomorrow. If that improvement is done today, instead of tomorrow; by his majesty, instead of another person; history would acknowledge you for not only laying the foundation, but also for concluding Ethiopia's development. ${ }^{54}$

Obviously, Haddis's suggestion was considered a challenge to the government and it created tension between Haddis and the emperor, who summoned Haddis to his palace and was said to have rebuked him for a radical stand. ${ }^{55}$

Here, the personality of Haddis deserves mention. According to Clampham, "Haddis has a reputation [of being] honest and painstaking administrator. ${ }^{56}$ My informants also confirmed this. They said, he was open and forwards his feeling directly to the emperor including his view against any mistake of the royalty. In his long service, Haddis was always admired for his humbleness, honesty and genuineness. Overall, his modesty and far sightedness were incomparable. And he always longed for better administration and for changes that could bring Ethiopia into better level of development. ${ }^{57}$

Despite his challenge, on 9 February, 1961, Haddis was appointed Minister of State in the Ministry of Education. ${ }^{58}$ That means, he was a de facto minister acting for the emperor, who had so far held the position of the Minister of Education himself to exhibit his actual concern for education. Although Haddis served at ministerial level, it was Emperor Haile Selassie I who was known officially as Minister of Education. This condition was said to have prevented Haddis to work freely. As a

\footnotetext{
${ }^{55}$ Ibid.; Haddis Alemayehu, Ytyopia Min Ayinet Astadader Yasfalgatal, p. I

56 "Leyu Mastawesha", pp. 9-10: Translated from a manuscript written in Amharic

${ }^{57}$ O.I. Blatta Mehari Kassa

${ }^{58}$ Clapham, p. 194

${ }^{59}$ O.I. Ato Tekalign Gedamu (age 64, interviewed in Addis Abeba on 24 Dec. 1998); Blatta Mehari Kassa

${ }^{58}$ Ethiopian Herald, February 10, 1961, p. 1
} 
result, he stayed only for five months in the new office. ${ }^{59}$ But before leaving this office, there was a conference of African states in Addis Ababa that dealt with the development of education in the continent. In this conference, Haddis was said to have reported the actual number of schools and students found in Ethiopia. However, the emperor was not happy for he understood that the statistical report presented was less than any other African country. ${ }^{60}$ This displeasure has grown into a serious tension between Haddis and the emperor when UNESCO published educational statistics of African countries which disclosed that Ethiopia's educational system has failed behind most African countries. Greenfield mentioned the tension that developed between the two as follows:

When UNESCO published comparative statistics for African countries in 1961, Haile Selassie refused to believe them and tension developed between him and the minister of state responsible for education [HaddisAlemayehu] ${ }^{61}$

The participants of this conference pledged to remove illiteracy from the continent within twenty-five years. ${ }^{62}$ To this end, Haddis, along with other experts of the Ministry of Education, was reported to have prepared a plan and submitted to the government. Generally, the budget assigned for education was very small and inadequate, out of which nearly 75 percent was allotted for the administrative sector. Haddis proposed that the administrative sector should take only 25 percent of the budget leaving the rest to fulfill educational facilities. It was also proposed that except formulating plans and supervision of achievements, the Ministry of Education should leave the execution of the plan to responsible bodies such as educational institutions and experts. ${ }^{63}$

However, the plan itself met serious opposition and even the existing budget was reduced by quarter. At this time, Haddis understood that the government was not ready to implement the decision passed by the 1961 conference of African states on education. As a result, Haddis presented his resignation to the government. ${ }^{64}$ Clapham has observed the tension that developed between Haddis and Emperor Haile Sellase I and asserted:

At the ministry of education, Haddis Alemayehu lost his job after revealing that Ethiopia was educationally well behind most other African countries, a revelation which greatly weakened the

\footnotetext{
${ }^{59}$ Molvaer, p. 142

${ }^{62}$ O.I. Blatta Mehari Kassa

${ }^{63}$ Greenfield, p.472

${ }^{64}$ Molvaer, p.142

${ }^{65}$ Bekur, p. 28

${ }^{66}$ Molvaer, p. 143
}

emperor's carefully built up image as keen supporter of educational advance. ${ }^{65}$

In the meantime, interchanging of junior officials of the Ministry of Education time and again had been customary. Regarding this issue there was a joke reported to have been stated by the officials of the ministry. The joke reads: "The vice-ministers or assistant ministers responsible for education had time only to give one order before a general Shumshir [demotion and promotion] dictated their translation to another ministry or an embassy overseas." 6

Following his resignation from his post in the Ministry of Education at the end 1961 Haddis was sent to London as Ethiopia's Ambassador to Great Britain and the Netherlands and stayed there until $1966 .{ }^{67}$ While in London, Haddis lost his beloved wife, whom he married by Holy Communion. She died in America, where she went for higher medication. Her corpse was taken to Jerusalem and buried there. ${ }^{68}$ Their marriage was childless and Haddis led a lonely life until his death. Haddis had great respect and love for his wife. Following her death, he handed over their home found in Qechene to Addis Ababa municipality to make it a children care center in commemoration of his wife. ${ }^{69}$

Starting from April 1966 Haddis became the member of the Cabinet. This was following the political reform of the emperor which was issued on 24 March, 1966, when he appointed AkliluHabta-Weld as Prime Minister and gave him the authority to choose his ministers. Then the Prime Minister asked Haddis to come back from London and join a new cabinet to be formed. ${ }^{70}$ After long discussion on the issue, Haddis became the Minister of the Ministry of Planning and Development on 11 April $1966 .{ }^{71}$ There was no such a ministry in the country before his appointment but the Planning Board run under Prime Minister's Office. ${ }^{72}$

According to informants, before April 1966 the work of planning was not conducted in organized way. But after the formation of the ministry, Haddis was said to have gathered domestic and foreign educated young Ethiopians and organized the ministry with skilled man power. ${ }^{73}$ It was during this time that the Third Five Year Developmental Plan (1968/9-1972/3), which embraced provisions for agriculture - a sector neglected by the earlier two developmental plans -, was prepared. ${ }^{74}$

\footnotetext{
${ }^{67}$ Clapham, p. 97

${ }^{68}$ Greenfield, pp. 334-35

${ }^{69}$ Molvaer, p. 143

${ }^{70}$ Bekur, p. 28

${ }^{71}$ Ibid.; O.I. Bitweded Zewde Gebre Hiwet and Blatta Mehari Kassa

${ }^{70}$ O.I. Ato Tekalign Gedamu

${ }^{73}$ Ethiopian Herald, 1966, p. 3

${ }^{74}$ O.I. Ato Tekalign Gedamu

${ }^{75}$ Ibid.

${ }^{74}$ Markakis, p. 346
} 
According to Markakis, the execution of the Third Five Year Developmental Plan was intimidated by unwillingness of Yelma Deressa, Minister of Finance, to cooperate for the implementation of the plan. ${ }^{75}$ Yelma argued against the budget allocated for the implementation of the plan in view of the financial problem caused by the global political instability in connection with the closing of the Suez Canal. ${ }^{76}$

Haddis did not agree with Yelma's stand. However, convinced by the statement of Yelma Deressa, the parliament decided to reduce the budget previously approved for the execution of the Third Five Year Developmental Plan by half. Haddis was highly disappointed with the reduction of the budget for he understood that the newly established ministry was unable to carry out its tasks with the budget allocated to it. This once again forced Haddis to submit his letter of resignation to the government. ${ }^{77}$

In the meantime, a few ministerial changes were made by a cabinet. The reshuffling was proclaimed on 18 February 1969. By the new arrangement, Haddis became a Senator and his former ministry was also reduced to a Planning Commission and put under Prime Minister's office. ${ }^{78}$ Haddis remained a Senator until the outbreak of the 1974 revolution. ${ }^{79}$

While the revolution was in progress, the Derg - the Coordinating Committee of Armed forces, the Police and the Territorial Army - was said to have asked Haddis to become the Prime Minister of Ethiopia. ${ }^{80}$ The story of this issue goes as follows. Beginning from 1973, there was all sort of social unrest in the country. The government was incapable in dealing with the problems. In February 1974, Prime Minister Aklilu Habta-Weld resigned and Endalkachew Mekonnen took his place. ${ }^{81}$ On 29 June, 1974 , the Derg was formed. Soon, the Derg demanded the change of the Prime Minister. ${ }^{82}$ It also set the criteria for the selection of the Prime Minister which include intellectuality, long years of experience, popularity, support to the objectives of "Ethiopia First", and willingness to work with the Derg. ${ }^{83}$ The first candidate of the Derg for the position of Prime Minister was Haddis Alemayehu. ${ }^{84}$

The Derg has reasons to propose Haddis for this

\footnotetext{
${ }^{75}$ Ibid, p. 353

${ }^{76}$ Bekur, p. 29

${ }^{79}$ Ibid.

${ }^{78}$ Clapham, p. 199

${ }^{79}$ Molvaer, p. 144

${ }^{80}$ Abera Jembere , Yesirbetu Abessa Betalaku Betmengist("The Misfortune of the Prison House in the Great Palace”): 1966-1974 E.C.( Addis Abeba. 1985 E.C.), p.36

${ }^{81}$ O.I. Lej Mikael Emeru

${ }^{82}$ Ibid., Abera p. 36;

${ }^{83}$ Fikre-Sellase Wegderess, Egna na Abiotu ("Us and The Revolution”). (Los Angeles: TSEAHI, Publishers, 2006 E.C.), p.87

${ }^{84}$ Ibid., Abera, p.36
}

position. Haddis has got appreciation and reputation of the peoples of Ethiopia by his novel FekerEskeMeqabir ("Love unto Grave").The members of the Derg were not exceptions. Above all in his book Haddis gave detailed explanations on the horror of the feudal system that prevailed in the country for longer period of time. As a result, the Derg considered Haddis as a man having antifeudal stand and the members of the Derg hoped that Haddis would fully support the program of the Derg. Thus, the Derg unanimously agreed for the appointment of Haddis as Prime Minister of the country. ${ }^{85}$ The demand of the Derg was forwarded to Haddis Alemayehu through General Aman Andom, Chief of Staff of the Armed Forces. In the meantime, Haddis is reported to have questioned General Aman what the program of the Derg was, during which the latter was said to have replied "Our Program is Ethiopia First!." But Haddis was not satisfied by what General Aman has said. What Haddis expected from General Aman was a program that would foster Ethiopia's development. As a result, Haddis did not accept what the General has said and suggested that he would agree to his appointment if he would be allowed to design a program and that all members of the army would agree to return to their barracks. ${ }^{86}$

In the next day, General Aman had reported to the Derg as if Haddis has refused his appointment as Prime Minister of the country without explaining the suggestions forwarded by him. Having received this report, the Derg continued discussion to select another candidate to the position of Prime Minister. It was this time that Lej Mikael Emeru was proposed by Mengistu Haile-Mariam, chairman of the Derg, for this position, and finally the Derg made Lej Mikael Emeru Prime Minister on 22 July, $1974 .{ }^{87}$ However, the popular uprising continued unabated and on 12 September, 1974, Emperor Haile Selassie I was overthrown from the political power and the proclamation that deposed the emperor transferred the Derg into the Provisional Military Administrative Council assuming full state power. ${ }^{88}$

In September 1975, the Derg established Yememakirt Shengo (National Advisory Assembly). Its declared objective was to provide advice to the Derg on the country's economic, political, social, developmental and other national issues. This Advisory Assembly was composed of knowledgeable and well-experienced individuals from different ministries, provinces, institutions and organizations. ${ }^{89}$ The National Advisory Assembly was also intended to replace the old parliament. At this time, the Derg told Haddis that he was chosen by the

\footnotetext{
${ }^{85}$ Fikre-Selassie, p. 87

${ }^{86}$ Bakur, p.29

${ }^{87}$ Abera, p. 36; Fikre-Selassie, pp. 88-89; O.I. Lej Mikael Emeru

${ }^{88}$ Bahru, pp. 235-36

${ }^{89}$ Fikre-Selassie, pp.211-13
} 
people of Gojjam to be their representative in the Advisory Assembly or parliament. Haddis also welcomed the request and served in this Advisory Assembly for two years until his final retirement. ${ }^{90}$

In addition to his political endeavor, Haddis was also one of a few Ethiopians who made great contribution to the literary development of the country. Of course, he is considered one of the pioneers of Amharic literature. His inclination towards literary work began while he was a student in Teferi Mekonnen Elementary School. However, he did not publish a book before 1956. His mastery of Amharic language and his vast experience in the life and history of his country and those of foreign countries seems to have helped him develop an interest in literature. ${ }^{91}$ Haddis wrote seven books in Amharic. These consisted of a fable, Teret Teret Yemeseret /"aggregation of tales"/, published in 1948 E.C., three novels, Feqer Eske Meqabir /"love unto grave"l, Wenjelegnaw Dagna /"the criminal judge"/ and Yelmjat /"plenty of dreams"I published in 1958, 1974 and 1980 E.C., respectively, and non-fictional works such as Yetimihrtina Yetemari Bet Tirgum /"the meaning of education and school"/, Ytyopia Min Aynet Astedader Yasfeligatal? /"What type of government Ethiopia needs? "/ and Tezeta /"memory"/ published in 1948, 1966 and 1985 E.C., respectively. Due to his immense contribution for the development of Ethiopian literature, Haddis Alemayehu was awarded the Haile Selassie I Award Trust Prize Medal and Golden Mercury Prize in 1969 and he also received an honorary Doctoral Degree from Addis Ababa University in $2000 .{ }^{92}$

\section{Conclusion}

Kibur Ato Haddis Alemayehu's political career as senior official of Ethiopia during the reign of Emperor Haile Selassie I start after his return from confinement in Italy at the end of 1943. In the post-liberation period, Haddis served his country at different governmental posts. Most of his service was in the area of foreign affairs at domestic and international levels. In addition to his regular duty as a diplomat Haddis had participated in a number of international as well as continental conferences by representing the government of Ethiopia. In his dealing with other countries on behalf of the Ethiopian government, Haddis was committed to protect Ethiopia's interest, sovereignty and territorial integrity. At home, Haddis had a reputation of honest and meticulous administrator and bold enough to comment any mistake of the

\footnotetext{
${ }^{90}$ Molvaer, pp. 144 - 45

${ }^{91}$ O.I. Ato Berhanu Gebeyehu (age 33, interviewed in Addis Abeba on 16 Dec.1998)

${ }^{92}$ Ibid., Fentahun, pp. 33-34
}

government. Haddis lost his wife, whom he married by Holy Communion, while he was in London. Since their marriage was childless, Haddis led a lonely life for about forty-two years in his home found north of Urael Church in Addis Ababa until his death. Finally, Haddis Alemayehu passed away after a long illness on 6 December, 2003 at the age of 94 . His funeral ceremony was held at Holy Trinity Cathedral with the presence of the Patriarch of the Ethiopian OrthodoxChurch His HolinessAbune ${ }^{93}$ Paulos, senior government officials, friends and relatives of the deceased.

\section{Conflict of Interests}

The author has not declared any conflict of interests.

\section{REFERENCES}

Abdulsamed HA (1977). "Bure - A Study of Long Distance Trade 1900 1935." B.A.Thesis. Addis Abeba University.

Abera J (1985). Ye Sir Betu Abessa Be Talaqu Betemengest ("The Misfortune of the Prison House in the Great Palace"): 1966-1974 E.C. Addis Abeba.

Bahru Z (2005). A History of Modern Ethiopia: 1855-1991. Second Edition. Addis Ababa: Addis Abeba University Press.

Clapham C (1969). Haile Sellase's Ethiopia. New York: Praeger.

Fentahun E (2000). Tarikawi Mezgaba-Sab: Ka Tinant Eska Zare (" A Historical Dictionary: from Past to Present"). Addis Ababa.

Fikre-Selassie W (2006). Egna na Abiotu ("Us and The Revolution"). Los Angeles: TSEAHI Publishers.

Girma A (2004). Addis Alemayehu (1910-2003). In Int. J. Ethiopian Stud. 1(2).

Greenfield RA (1965). Ethiopia: A New Political History. New York: Fredrick A. Preager.

Haddi A (1966). Ytyopia Min Ayinet Astedader Yasfelgatal ("What Type of Government Ethiopia Needs?"). Addis Abeba: Birhanena Salam Printing Press.

Haddi A (1985). Tezetta ("Memory"). Addis Abeba: Kuraz Publishing Agency. "Leyu Mastawesha" ("Special Note"). Tir 23, 1953 E.C. (Obtained in Haddis's Home in1998).

Markakis J (1974). Ethiopia: Anatomy of Traditional Polity. Addis Abeba: Oxford University Press.

Mesfin Wolde-Mariam. (1964). The Background of the Ethio- Somalia Boundary Dispute. Addis Abeba: Haile Selassie I University.

Molvaer R (1996). Black Lions: the Creative Lives of Modern Ethiopia's Literary Giants and Pioneers. Lawrenceville, NJ: Red Sea Press.

Spencer JH (1984). Ethiopia At Bay: A Personal Account of the Haile Sellase Years. Algonac, Michigan.

Tsegaye H (1987). "Haddis Alemayhu as a Social Critic." M.A.Thesis in Literature (English). Addis Abeba University.

\section{CITATIONS}

Bekur (Bulletin of Amhara National Regional State) No-6, Sene 1989 E.C.

Ethiopian Herald, February 10, 1961.

Ethiopian Herald, April 13, 1966.

\footnotetext{
${ }^{93}$ The highest ecclesiastical title of the Ethiopian Orthodox Church
} 
Feekare (Private Bulletin), Vol-I, No.1, Yekatit, 1985 E.C.

Most of the meanings of the traditional titles formerly and currently used in Ethiopia are taken from Bahru, pp. 275-77.

${ }^{\mathrm{i}}$ A title given in Ethiopia to highly authorized and respected individuals. It is equivalent to His Excellence

ii A title given for adult man. It is equivalent to $\mathrm{Mr}$. 